\title{
PRODUCT PACKAGING: IMPACT ON CUSTOMERS' PURCHASE INTENTION
}

\author{
Sook-Fern Yeo* \\ Multimedia University \\ Cheng-Ling Tan \\ Universiti Sains Malaysia \\ Kah-Boon Lim \\ Multimedia University \\ Yong-Hwi Khoo \\ Multimedia University
}

\begin{abstract}
This research aims to investigate the impact of packaging on customers' purchase intention in Malaysia. Many studies show that the outward appearance of a product's package will appeal and consumers' attention towards the products displayed in the open market. Since the consumers' choice is the primary consideration that marketers emphasize on, packaging has become an important tool for sales promotion by most business organizations. Although a large number of factors can impact customers' purchase intention, a product's packaging is the most influential. Therefore, this research looked into the extent of how packaging has influenced the purchase intention of customers. Findings from the study show that three hypotheses out of four were supported which lend support to the vital role that packaging plays in creating appeal and influencing customers' purchase intention. The conclusion of this study provides the theoretical implications and practical implications as well as suggestions for future studies in different industries.
\end{abstract}

Keywords: Product packaging; Colour; Materials; Size and shape; Purchase intention; Malaysia.

\section{INTRODUCTION}

The high level of competitiveness between business environments has certainly intensified the marketability of products to meet the needs and wants of customers. To capture and sustain customers' purchase intention, packaging has become an essential tool in the way business organisations conduct their sales promotion. The strategic use of packaging can increase the sales and market share of a particular product and interestingly, even defray and decrease the company's market and promotional costs as more and more customers are attracted to their products. This is supported by Rundh (2005) who stated that product packaging can impact and influence the

\footnotetext{
- Corresponding author: Yeo Sook Fern, Faculty of Business, Multimedia University, 75450 Melaka, Malaysia; Tel: +606-2524876; E-mail: yeo.sook.fern@mmu.edu.my
} 
opinions of consumers, draw in consumers' attention and stimulate consumers' perceptions into forming their purchase intentions about a particular product. Furthermore, Ibojo and Olawepo (2015) concur that packaging will deliver a brand new image or value to the existing product and help consumers to differentiate from products that have similar characteristics. In other words, the unique value of packaging can attract and influence consumers to pick out their ideal product from the extensive variety of similar products found in the market.

Catering to a wide range of consumers' needs and wants has pushed Malaysian companies to seek novel ways of packaging to attract, maintain and sustain consumers" purchase intention. There are various packaging types and closures that are easily available: metal packaging, rigid plastic, glass, liquid cartons, paper-based containers, etc. To assess the packaging industry in Malaysia, we have to examine some of the most dynamic factors that guide Malaysian manufacturers to determine the type of packaging that can boost their market growth.

First of all, recyclability has become a major concern in the world today and with a large number of environmental-friendly consumers within our midst, manufacturing sectors are driven to look for packaging that attracts consumers' in general to support not only their product but also their efforts to protect the environment. Thus, there is a high demand for recyclable packaging which has a bright prospect and is worth looking into. Nowadays consumers prefer to buy products that have recyclable packaging due to the wide attention given by global movements to recycle and save the environment. There are mainly two types of recyclable packaging: paper packaging and corrugated packaging. Within the recycled materials market, paper packaging is the largest sector, accounting for around $65 \%$ of all recycled packaging. Demand for paper packaging will keep on rising as it is affected by the manufacturing economies of China and other emerging countries. Analysts predict the overall market for recycled paper packaging to grow at a compound annual growth rate (CAGR) of 5\% to reach $\$ 139$ billion in 2018 (Anne, 2014).

Flexible packaging is also one of the most dynamic packaging types in Malaysia. Due to high barrier properties, long-lasting feature and cost-effectiveness, plastic has been used widely for packaging. In 2012, plastic accounted for over $70 \%$ of market share. The food and pharmaceutical industries in Malaysia have the highest usage of plastic packaging in Malaysia. Malaysian food consumption was estimated to reach US\$2 billion in 2017 while pharmaceutical productions will increase to US\$5 billion by 2023 (Printing Review Graphic Arts Magazine, 2016). Nevertheless, the growing awareness among the public has shrunken the use of plastic and many have opted for an eco-friendlier material - cellulose. More easily recyclable materials such as mono-layers are expected to be brought in over the next 10 years but real improvement will only come with enhanced collection, sorting and recycling infrastructure. With a variety of packaging materials easily available to them, manufacturers have the onus of choosing suitable materials and designs that appeal to their consumers and influence their purchase intention. Therefore, the main purpose of this research is to investigate how four factors such as packaging colour, packaging material, packaging design and packaging graphics influence the customers' purchase intention. 


\section{LITERATURE REVIEW}

\subsection{Purchase Intention}

Purchase intentions are known as moving forward a planned decision to purchase specific products in future and it is not necessary to implement the buying intention because it depends on an individual's capability to implement it (Yeo, Tan, Lim, Leong \& Lee, 2018). Liat and Wuan (2014) stressed that when an individual has the arrangement to purchase a specific item or service over a period of time, the purchase intention will arise. Their intention to buy will be influenced by their conduct, their recognition of the product and their disposition (Keller, 2009). The purchase intention of consumers has become an interesting area of study by marketing experts (Hosein, 2012) to examine shopper recognitions and procedures as well as to investigate customers' purchase intention (Javed, Ahmed, Nawaz, \& Sajid, 2016). Correspondingly, Yeo, Lim, Goh and Tan (2015) mentioned that customers' purchase intention is an important key factor for a company to be gain a competitive edge in the market place. Furthermore, Chi (2013) found that consumers' purchase intention becomes a vital key to anticipate the buying behaviour that can be found through the advantages and values procurement of a specific product or service. Past research stated that purchase intention is utilized to become the best apparatus when marketers attempt to investigate the buying process of consumers.

\subsection{Packaging Colour}

Every colour owns special meaning which can influence consumers' feelings and mindsets. Colour is the most important element of packaging where different types of colour will affect the consumers to have a different view or opinion towards the packaging (Keller, 2009). Keller (2009) also stated that the colour of the packaging is an imperative component that will help the consumer to differentiate from other products with similar characteristics that are offered by competitors. Some of the researchers stated that the colour of packaging will influence the purchase intention of consumers when consumers relate to the new styles of packaging for a new product that has a similar colour with the original product bundle (Ibojo \& Olawepo, 2015). Previous studies by Javed and Javed (2015) stated that making the right choice of colour for the packaging will have the power to attract the consumer's attention. However, the wrong choice of colour will result in a loss of interest by consumers toward the product. The colours that are used by the packaging all have their significance in appealing and stressing different moods (Ali et al., 2015). The study also determines that packaging colour of product induces the purchase intention of the customer, packaging colour can be remembered and packaging colour does bring competitive advantages to company With this convincing literature, the first hypothesis is developed as:

\section{H1: There is a significant positive relationship between packaging colour and customer purchase intention}

\subsection{Packaging Material}

Packaging material is used to wrap a product on the exterior to prevent a product from being damages (Ali et al., 2015). Correspondingly, the packaging material is said as the tool to communicate the value of the product to the customer. The perceived quality of the product may affect by the packaging material used and packaging material can avoid the product from being 
damaged (Farooq, Habib \& Aslam, 2015). Following a study of Mutsikiwa and Marumbwa (2013), the material that people used for packaging in the past was mostly natural materials that was easy to obtain without much processing required. Naturally, consumers are more inclined towards a product which has packing material of superb quality compared with a product that has low-quality packaging (Zekiri \& Hasani, 2015). They also stated that packaging materials have a strong impact on buying behaviour that will influence the customers' purchase intention. Additionally, Zekiri and Hasani (2015) also stated that packaging materials have a strong impact on buying behaviour that will influence customer purchase intention. However, over time. the materials used for packaging also evolved into material that is being processed to enhance their quality and durability (Mutsikiwa \& Marumbwa, 2013). The material for packaging material is a vital component that keeps the item from being damaged thus incurring losses. Hence, the second hypothesis tested in this study is:

\section{H2: There is a significant positive relationship between packaging material and customer purchase intention}

\subsection{Packaging Graphic}

The graphic for packaging is defined as the pictures that are made on the packaging whether these pictures are deliberately created specialized for a particular product or unintended and unexpected (Silayoi \& Speece, 2007). According to the studies of Smith (2004), the graphic design of the packaging such as the image on the packaging will help to build the brand of the product to make it more special and to create its own identity so that consumers can differentiate it from a similar product manufactured by their competitors. Besides that, through the research of Farooq et al., (2015) it was also found that the higher the quality of the graphic for packaging, the likelihood of consumers feeling assured about the quality of the product. According to Akbari, Gholizadeh and Zomorrodi (2014), the picture on packaging is a way to attracting consumers buying intentions. From the studies of Ali et al. (2015) about packaging, the right selection about the image for a product packaging that related and identified to the brand can help to draw the attention of consumers that help to influence the consumers' purchase intention. With this convincing literature, the third hypothesis is developed as:

\section{H3: There is a significant positive relationship between packaging graphics and customer purchase intention}

\subsection{Packaging Size and Shape}

The packaging size and shape is defined as how big the item is and the appearance outline of the item (Silayoi \& Speece, 2004). According to Ali et al., (2015) a study on packaging found that the size and shape of packaging will influence the purchase intention of consumers who prefer the design of packaging that is convenient. Consumers will be attracted with the outward appearance of packaging which is large but if the item inside the packaging is small or low in quantity, the customer will not have a repurchase intention towards the particular product again (Ali et al., 2015). Consumers feel the packaging of products in large sizes give them better value in contrast with product packaging that comes in small sizes (Ali et al., 2015). When the consumers cannot define the quality of the product by the appearance of the packaging, the packaging size will have a very strong impact towards the customers' purchase intention (Silayoi \& Speece, 2007). According to 
research done by Agariya et. al. (2012), consumers will have an association with a particular product by seeing the outline shape of the packaging. With this convincing literature, the fourth hypothesis is developed as:

\section{H4: There is a significant positive relationship between packaging graphics and customer purchase intention}

\section{METHODOLOGY}

The purposive non-probability sampling technique is employed in the present study. The questionnaires were distributed to 250 respondents in Melaka and Johor Bahru from September to December 2017. A total of 212 questionnaires were returned and only 200 is usable for further analysis. The measures used to operationalize the constructs included in the investigated models and the questionnaires were mainly adapted from previous studies. All items were measured using a 5 -point Likert-type scale with anchors on $1=$ strongly disagree and $5=$ strongly agree respectively.

Figure 1: Conceptual Framework

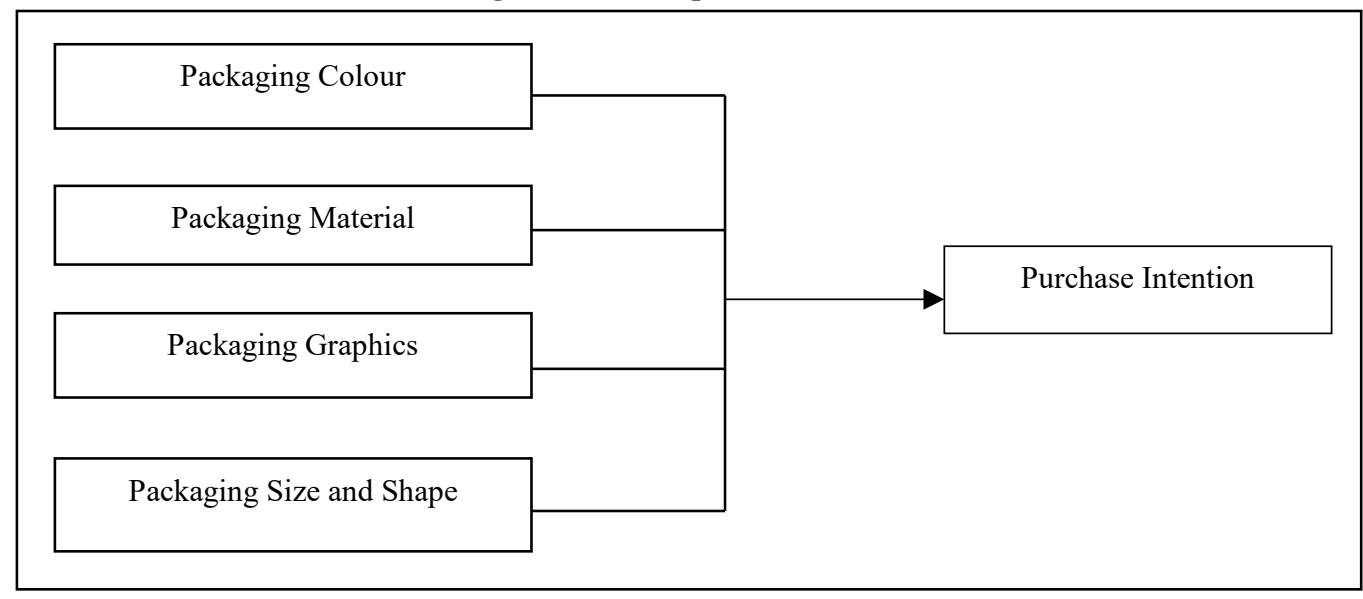

\section{RESULTS AND DISCUSSION}

Target respondents of this research will be the general public in Malaysia and the sample size will be a minimum of 129 people in Malaysia, suggested by G*Power. The response rate was $94.34 \%$ where 200 people answered and collected back the questionnaire as 250 survey questionnaires were distributed to people. The response rate was higher than $90 \%$ because the answered questionnaires were reclaimed by the researcher via face to face interviews with the respondents.

The frequency and percentage of general demographic data of the respondents which consist of gender, race, age, occupation and marital status. The percentage of male and female respondents 
are $45 \%$ and $55 \%$ respectively. Besides, majority of the respondents are Chinese $(55 \%)$, followed by the Malays $(23.5 \%)$ and Indians $(21.5 \%)$. The highest age group of respondents come from those who aged between 20 to 29 years old (71\%) and the least percentage of participants are from those aged below 20 years old (0.5\%). Of the 212 respondents, $59.5 \%$ are student, while only $1 \%$ of the respondents are the retirees.

Table 1: Reliability Results

\begin{tabular}{lc}
\hline \hline \multicolumn{1}{c}{ Items } & Cronbach's Alpha Value \\
\hline Packaging Colour & 0.905 \\
Packaging Material & 0.813 \\
Packaging Graphic & 0.904 \\
Packaging Shape and Size & 0.844 \\
Purchase Intention & 0.809 \\
\hline \hline
\end{tabular}

Cronbach's Alpha value range within 0 to 0.5 is not acceptable, 0.6 to 0.7 is acceptable, while 0.8 to 0.9 can be considered as excellent (Ali et al., 2015). Table 1 shows packaging colour, packaging material, packaging graphic, packaging shape and size and purchase intention. The Cronbach's Alpha value for purchase intention is 0.809 and independent variable which consists of packaging colour, packaging material, packaging graphic, packaging shape and size are $0.905,0.813,0.904$ and 0.844 respectively. Overall, all the variables were reliable.

The $\mathrm{R}$ square value was 0.667 which means there is $67.7 \%$ of the dependent variable which is purchase intention was affected by the independent variables which are packaging colour, packaging material, packaging graphic and packaging size and shape.

Table 2: Hypothesis Results

\begin{tabular}{lcccccc}
\hline \hline \multirow{1}{*}{ Model } & \multicolumn{2}{c}{$\begin{array}{c}\text { Unstandardized } \\
\text { Coefficients }\end{array}$} & $\begin{array}{c}\text { Standardized } \\
\text { Coefficients }\end{array}$ & t & Sig & Result \\
\cline { 2 - 4 } & B & $\begin{array}{c}\text { Std. } \\
\text { Error }\end{array}$ & Beta & & & \\
\hline \hline $\begin{array}{l}\text { Packaging } \\
\begin{array}{l}\text { Colour } \\
\text { Packaging }\end{array}\end{array}$ & -0.169 & 0.052 & -0.249 & -3.240 & 0.001 & H1 supported \\
$\begin{array}{l}\text { Material } \\
\text { Packaging }\end{array}$ & 0.164 & 0.040 & 0.210 & 4.134 & 0.000 & H2 supported \\
$\begin{array}{l}\text { Graphic } \\
\text { Packaging Size } \\
\text { and Shape }\end{array}$ & 0.608 & 0.600 & 0.807 & 10.138 & 0.000 & H3 supported \\
\hline \hline
\end{tabular}




\section{CONCLUSION}

The main objective of this study is to investigate the impact of packaging on the customer purchase intention in Malaysia. The results from this study have indicated that only packaging size and shape are not supported whereas there other three hypotheses of packaging colour, packaging material and packaging graphic which are supported. This research will be very valuable to the packaging industry in Malaysia because there is limited research about the packaging industry in Malaysia. To attract the customer purchase intention with product packaging, the packaging industry must know about what the customers' needs and wants are to fulfil their requirements. This research will assist the packaging industry in Malaysia to determine the factors of packaging that can enhance the customers' purchase intention. Future study can be conducted with the inclusion of customer satisfaction as the mediator.

\section{REFERENCES}

Agariya, A. K., Johari, A., Sharma, H. K., Chandraul, U. N., \& Singh, D. (2012). The role of packaging in brand communication. International Journal of Scientific \& Engineering Research, 3(2), 1-13.

Akbari, M., Gholizadeh, M. H., \& Zomorrodi, M. (2014). Purchase intention of products with Islamic labels under time pressure. Marketing and Branding Research, 1(1), 14-26.

Ali, S., Ahmad, S. F., Hussain, S., Ibrahim, M., \& Noreen, A. (2015). Impact of product packaging on consumer perception and purchase intention. Journal of Marketing and Consumer Research, 10, 1-9.

Anne, M. M. (2014, June 25). Recycled paper packaging market to grow to \$139B by 2018. Two Sides. Retrieved from https://twosidesna.org/US/recycled-paper-packaging-market-togrow-to-139b-by-2018/

Chi, H. (2013). The influences of perceived value on consumer purchase intention: The moderating effect of advertising endorser. Journal of International Management Studies, 23(3), 456543.

Farooq, S., Habib, S., \& Aslam, S. (2015). Influence of product packaging on consumer purchase intentions. International Journal of Economics, Commerce and Management, 3(12), 538 547.

Hosein, N. (2012). Measuring the purchase intention of visitors to the auto show. Journal of Management \& Marketing Research, 9(1), 1-17.

Ibojo, B. O., \& Olawepo, G. T. (2015). The relationship between packaging and consumers purchase intention: A case study of Nestlé Nigeria product. International Business and Management, 10(1), 72-81.

Javed, S. A., \& Javed, S. (2015). The impact of product's packaging color on customers' buying preferences under time pressure. Marketing and Branding Research, 2(1), 4-14.

Javed, S. A., Ahmed, F., Nawaz, M., \& Sajid, A. (2016). Identification of the organizational and managerial characteristics of organizations operating in project conducive environment - a preliminary study. Durreesamin Journal, 2(1), 1-6.

Keller, K. (2009). Strategic brand management: Building, measuring, and managing brand equity (4th ed.). Upper Saddle River, NJ: Pearson/Prentice Hall. 
Liat, C. B., \& Wuan, Y. S. (2014). Factors influencing consumers' online purchase intention: A study among university students in Malaysia. International Journal of Liberal Arts and Social Science, 2(8), 121-133.

Mutsikiwa, M., \& Marumbwa, J. (2013). The impact of aesthetics package design elements on consumer purchase decisions: A case of locally produced dairy products in Southern Zimbabwe. Journal of Business and Management, 8(5), 64-71.

Printing Review Graphic Arts Magazine. (2016). Pack print international 2017: Packaging and printing for the future. Retrieved from http://www.printingreview.in/packprint2017.html

Rundh, B. (2005). The multi-faceted dimension of packaging: Marketing logistic or marketing tool? British Food Journal, 107(9), 670-684.

Silayoi, P., \& Speece, M. (2004). Packaging and purchase decisions: A focus group study on the impact of involvement level and time pressure. British Food Journal, 106(8), 607-628.

Silayoi, P., \& Speece, M. (2007). The importance of packaging attributes: A conjoint analysis. European Journal of Marketing, 41(11/12), 1495-1517.

Smith, P. R., \& Taylor, J. (2004). Marketing communications: An integrated approach (4th ed.). London: Kogan Page Limited.

Yeo, S. F., Lim, K. B., Goh, M. L., \& Tan, S. H. (2015). The effect of celebrity endorser towards customer purchase intention. Advanced Science Letter, 21(6), 2164-2169.

Yeo, S. F., Tan, C. L., Lim, K. B., Leong, I., \& Lee, M. Y. (2018). Physical store purchase intention: the study of comics book in Malaysia. Global Business and Management Research: An International Journal, 10(3), 1035-1047.

Zekiri, J., \& Hasani, V. V. (2015). The role and impact of the packaging effect on consumer buying behaviour. ECOFORUM, 4(Special Issue 1), 232-240. 